\title{
Distribution patterns, larval growth and hatch dates of early stages of the mote sculpin Normanichthys crockeri (Scorpaeniformes, Normanichthyidae) in the upwelling ecosystem off central Chile
}

Patrones de distribución, crecimiento larval y fecha de eclosión de los estados tempranos del mote Normanichthys crockeri (Scorpaeniformes, Normanichthyidae) en el ecosistema de surgencias de Chile central

\section{Mauricio F. Landaeta ${ }^{1}$, Pedro A. Inostroza ${ }^{2}$, Argiro Ramirez ${ }^{3}$, Samuel Soto-Mendoza ${ }^{4}$ and Leonardo R. Castro ${ }^{4}$}

\author{
${ }^{1}$ Facultad de Ciencias del Mar y de Recursos Naturales, Universidad de Valparaíso, Avenida Borgoño 16344, Reñaca, Viña del Mar, \\ Chile.mauricio.landaeta@uv.cl \\ ${ }^{2}$ Programa de Investigación Marina de Excelencia (PIMEX-Nueva Aldea), Facultad de Ciencias Naturales y Oceanográficas, \\ Universidad de Concepción, Casilla 160-C, Concepción, Chile \\ ${ }^{3}$ Instituto Colombiano de Desarrollo Rural (INCODER), Bogotá, Colombia \\ ${ }^{4}$ Laboratorio de Oceanografía Pesquera y Ecología Larval, Departamento de Oceanografía, Centro FONDAP COPAS, Universidad de \\ Concepción, Casilla 160-C, Concepción, Chile
}

\begin{abstract}
Resumen.- Se examinó la variabilidad en la distribución espacial y temporal de los estados tempranos del mote Normanichthys crockeri en el ecosistema de surgencias de Chile central, utilizando la información de una serie de seis cruceros oceanográficos, crecimiento larval basado en otolitos, y experimentos de desarrollo embrional. Los adultos desovan durante todo el año en aguas superficiales cerca de penínsulas y dentro de bahías a lo largo de Chile central, reduciendo la advección costa afuera. Se observaron densidades de huevos de 16-788 $10 \mathrm{~m}^{-2}$. Eclosionan larvas pequeñas ( 2,7 mm de longitud corporal) alimentadas endógenamente por 6 días. Las larvas en pre y postflexión de $N$. crockeri se retienen sobre la plataforma continental o cerca de la costa, y están ubicadas verticalmente en la capa de mezcla de la columna de agua. No se detectó evidencia de migración vertical diurno-nocturna en las larvas durante primavera y verano. Las larvas de $N$. crockeri mostraron tasas de crecimiento lineal de 0,15-0,20 mm día ${ }^{-1}$ en los primeros tres meses de vida durante primavera y verano. Comparada con las tácticas reproductivas de otros peces pelágicos menores del área (Engraulis ringens y Strangomera bentincki), N. crockeri coincidió espacialmente en las áreas de desove, aunque las larvas presentaron tasas de crecimiento más lentas.
\end{abstract}

Palabras clave: Ictioplancton, desove, otolito, Pacífico suroriental

\begin{abstract}
The variability of spatial and temporal distribution of early stages of the mote sculpin Normanichthys crockeri from the upwelling ecosystem off central Chile was examined using a series of six oceanographic cruises, otolith-based larval growth, and experimental trials. Adults spawned year-round in surface waters near capes and inside bays along central Chile, which reduced offshore advection. Egg densities of 16-788 $10 \mathrm{~m}^{-2}$ were observed. Small larvae ( $2.7 \mathrm{~mm}$ body length) hatched after a few days and fed endogenously for 6 days. Pre and postflexion larval $N$. crockeri were retained over the shelf and near the coast and were vertically located in the mixed layer of the water column (from surface to $~ 50 \mathrm{~m}$ depth). No evidence of diel vertical migration was detected in larvae during the austral spring and summer seasons. N. crockeri larvae showed linear growth rates of $0.15-0.20 \mathrm{~mm}$ day $^{-1}$ in the first three months of life during spring and summer. Compared with the reproductive tactics of other small pelagic fishes from the area (Engraulis ringens and Strangomera bentincki), N. crockeri shared the same spawning areas; however larvae showed slower growth rate.
\end{abstract}

Key words: Ichthyoplankton, spawning, otolith, southeast Pacific

\section{INTRODUCTION}

In eastern boundary current ecosystems such as Humboldt ecosystem in the South Pacific Ocean, equatorward winds induce upwelling of nutrient-rich subsurface waters, with a subsequent high primary production (Montero et al. 2007). The high primary production and biomass of microalgae sustains highly concentrated schools of herbivorous small 
pelagic fishes, such as common sardine (Strangomera bentincki) and anchoveta (Engraulis ringens) (Barange et al., 2005, Pedraza-Garcia \& Cubillos 2008). In the area, coastal small pelagic fishes have evolved reproductive tactics to reduce advective transport from the coastal food-rich environment by spawning large amounts of small pelagic eggs (Cubillos et al. 2007) during seasons when upwelling events are scarce or absent, and when the abundance of gelatinous predators is low (Castro et al. 2000). This tactic, together with fast growing larval stage (e.g., $0.40-0.57 \mathrm{~mm}$ day $^{-1}$ for larval E. ringens, Hernández \& Castro 2000, $0.48 \mathrm{~mm}$ day $^{-1}$ for larval Sardinops sagax, Gaughan et al. 2001) may account for the success of these taxa in a productive environment. On the other hand, there is scarce knowledge about reproductive tactics and early life history of other highly abundant small pelagic fishes inhabiting upwelling areas, such as the mote sculpin, Normanichthys crockeri Clark, 1937 (Scorpaeniformes, Normanichthyidae).

The $N$. crockeri is a schooling, small-bodied (up to $11 \mathrm{~cm}$ total length) and short-lived pelagic fish endemic to the southeast Pacific, which inhabits coastal waters from Chimbote, Peru to $44^{\circ} \mathrm{S}$, southern Chile (Vegas \& Pequeño 1993, Landaeta \& Castro 2006a, Bustos et al. 2008). Adults feed on zooplankton, mainly copepods (Sepúlveda et al.2004) and show trophic interactions with several taxa, being preyed upon by coastal fishes (Vargas et al. 1999, Oyarzún et al. 2001, González \& Oyarzún 2003), seabirds (García-Godos \& Goya 2006) and marine mammals (Soto et al. 2006). Currently the eggs are unknown, while the larval stages are characterized by a slender body and large pectoral fins (Balbontín \& Pérez 1980, Vélez et al. 2003). Larvae feed on copepod eggs, copepodites and adult copepods (Balbontín et al. 1997). Spawning sites, early nursery areas and larval dynamics are unknown. This information is important from the ecological and fishery perspective, considering the fast increase of landings experienced along Chile in recent years (from 9,300 ton in 2003 to $\sim 67,000$ ton in 2008). The fishing period of this species off central Chile waters occurs during austral summer (February-May) and early spring (September-October), and it is part of the bycatch of small pelagic fisheries (G. Aedo, pers. comm. ${ }^{1}$ ). The hypothesis of this study is that early life history of this species is similar to other small pelagic fish, such as anchoveta and sardine, i.e., spawning in coastal, shallow waters during winter season, and fast growing larval stage. In this paper the objectives were 1) to describe the spatio temporal and vertical distribution of $N$. crockeri and 2) to estimate larval growth of $N$. crockeri in the upwelling ecosystem off central Chile coastal waters.

\section{Material ANd Methods}

\section{COLLECTION OF THE SAMPLES AND LABORATORY ANALYSIS}

A series of six surveys carried out over the continental shelf off central Chile between $33^{\circ} \mathrm{S}$ and $37^{\circ} \mathrm{S}$ were utilized to describe egg and larval distribution of $N$. crockeri (Fig. 1). A grid of 108 stations from inshore $(5 \mathrm{~km})$ to a maximum of $110 \mathrm{~km}$ offshore was sampled during the austral spring 1996 (25 September-29 October) onboard the RV Abate Molina. Conductivity-temperature-depth (CTD) (Sensordata ${ }^{\circledR}$ SD2003) casts to $100 \mathrm{~m}$ depth were conducted at each station in the sampling grid. Oblique tows were carried out at each station during day and night hours using a $1 \mathrm{~m}^{2}$ Tucker trawl ( $250 \mu \mathrm{m}$ mesh size) with a General Oceanics ${ }^{\circledR}$ flowmeter mounted in the frame

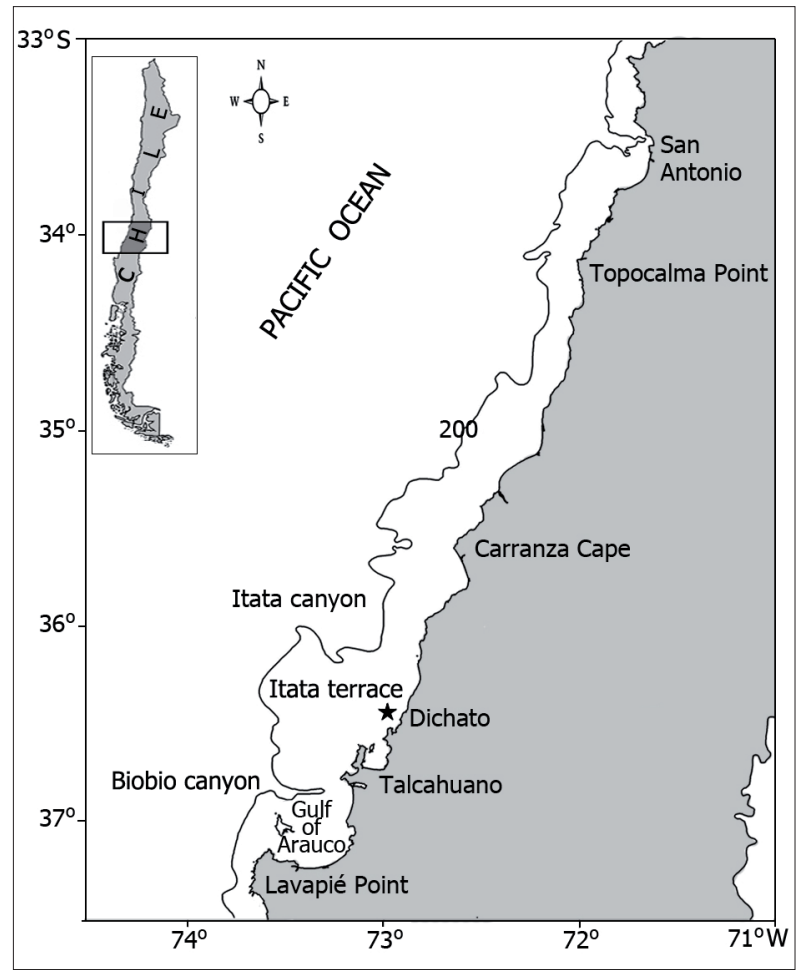

Figure 1. Central Chile study area, indicating the main topographic characteristics of the zone. The line corresponds to the $200-\mathrm{m}$ isobath and the star indicates the location of the coastal time series / Área de estudio en Chile central, indicando las principales características topográficas de la zona. La línea corresponde a la isóbata de $200 \mathrm{~m}$ y la estrella indica la ubicación de la serie de tiempo costera

${ }^{1}$ MSc. Gustavo Aedo, Facultad de Ciencias Naturales y Oceanográficas, Universidad de Concepción, Chile. 
of the net. Two depths strata were sampled, 0-40 m and 40-100 m. Towing speed was 2-3 knots. Volume filtered in each tow $\left(\right.$ range $=69-706 \mathrm{~m}^{3}$ tow ${ }^{-1}$; mean $=348 \mathrm{~m}^{3}$ tow $\left.{ }^{1}\right)$ was estimated taking into account the net mouth area and towing duration. Onboard, the samples were divided using a Folsom splitter and one subsample (i.e., 50\% of the whole) was preserved in $10 \%$ formalin buffered with sodium borate. The other subsample was preserved in $90 \%$ ethanol.

Two cruises were carried out during 7-11 November 2001 (austral spring) and 7-12 March 2002 (austral late summer) between $35^{\circ}$ and $37^{\circ} \mathrm{S}$ onboard the RV Abate Molina. Eleven transects with 6-7 stations each were sampled during both surveys. A CTD cast (Seabird ${ }^{\circledR}$ SB-19) was conducted at each station to $250 \mathrm{~m}$ or near the bottom. Oblique tows at speeds of 2-3 knots were carried out using a $1 \mathrm{~m}^{2}$ Tucker trawl $(300 \mu \mathrm{m}$ mesh size) with a General Oceanics ${ }^{\circledR}$ flowmeter mounted in the frame of the net to estimate filtered volume. Volume ranged between 17-598 $\mathrm{m}^{3}$ tow ${ }^{-1}\left(\right.$ mean $=142 \mathrm{~m}^{3}$ tow $\left.{ }^{-1}\right)$ during November 2001, and between 12-217 $\mathrm{m}^{3}$ tow $\left(\right.$ mean $=96 \mathrm{~m}^{3}$ tow $\left.^{-1}\right)$ during March 2002. Depth strata were variable, ranging from $0-10,10-25 \mathrm{~m}$ in nearshore waters, 0-25, 25-50, 50-75 and 75-100 $\mathrm{m}$ deep over the shelf, and 0-50, 50-100, 100-150 and 150-250 m deep at the shelf break area. Samples from each depth strata were preserved in 10\% formalin and 90\% ethanol.

During September 2004 and 2005 (austral late winter), 41 and 48 stations were surveyed, respectively, over the continental shelf between San Antonio ( $33^{\circ} 18^{\prime} \mathrm{S}$ ) and Gulf of Arauco (Fig. 1) onboard the RV Kay-Kay. At each station CTD casts (Seabird SB-19) and an oblique Bongo (60 cm diameter, $300 \mu \mathrm{m}$ mesh size, with General Oceanics $^{\circledR}$ flowmeter) tow to $80 \mathrm{~m}$ depth or near the bottom, were conducted during day and night hours, following Smith \& Richardson (1977). Towing speed was 2 knots. Filtered volume ranged from 7 to $200 \mathrm{~m}^{3}$ tow $^{-1}\left(\right.$ mean $=48 \mathrm{~m}^{3}$ tow $\left.^{-1}\right)$ for the 2004 survey, and from 15 to $142 \mathrm{~m}^{3}$ tow ${ }^{-1}$ (mean $=57 \mathrm{~m}^{3}$ tow ${ }^{-1}$ ) for the 2005 survey. The right sample was preserved in $10 \%$ formalin buffered with sodium borate and the left sample was preserved in 90\% ethanol.

Between July 2004 and June 2006, monthly samples of zooplankton were collected at three coastal stations located 5 nautical miles from the shore (Fig. 1), onboard RV Kay-Kay. Oblique samples were collected with a standard bongo net $(60 \mathrm{~cm}$ diameter, $300 \mu \mathrm{m}$ mesh size, General Oceanics ${ }^{\circledR}$ flowmeter), from $40 \mathrm{~m}$ depth to surface. Once onboard, samples were fixed in $10 \%$ formalin buffered with sodium borate.

All fish eggs and larvae were sorted from the plankton samples at the laboratory. Identification of larval $N$. crockeri was carried out utilizing characters described by Balbontín \& Pérez (1980) and Vélez et al. (2003). Egg and larval densities were expressed as individuals $10 \mathrm{~m}^{-2}$ for examination of horizontal distribution patterns (integrated samples) and as individuals $1000 \mathrm{~m}^{-3}$ for examination of vertical distribution (only Tucker trawl samples). Developmental stages of all larvae were classified as preflexion or postflexion (flexion and postflexion larvae pooled). In addition, undamaged larvae from the 2001 and 2002 surveys $(\mathrm{N}=66$ and 812 , respectively) were measured to the nearest $0.1 \mathrm{~mm}$ with a calibrated ocular micrometer fitted to a Nikon ${ }^{\circledR}$ stereomicroscope.

Non-parametric tests (Mann-Whitney U test) were run to compare the vertical distribution of early stages of $N$. crockeri. Additionally, the centroid depth distribution (CDD) of pre- and postflexion larvae collected during November 2001 and March 2002 were calculated separately for each station according to the formula:

$$
\mathrm{CDD}=\sum(p k \times z k) / \sum p k
$$

where $p_{\mathrm{k}}$ is the number of organisms at stratum $k$ (abundance standardized to individuals $1000 \mathrm{~m}^{-3}$ ), and $z_{\mathrm{k}}$ is the mean depth of stratum $k$. To establish if vertical migration occurred in both groups, the calculated centroid depths during day and night hours were compared using Mann-Whitney U-test.

\section{EGG IDENTIFICATION}

Normanichthys crockeri eggs were identified using the series method described by Neira et al. (1998), from zooplankton samples collected between 1996 and 2005. The method consists of positively identifying the largest available larva, using known adult characters and subsequently linking this specimen with progressively smaller specimens by using general morphological and pigment characters until a developmental series is assembled. Eggs and yolk-sac larval identifications were confirmed through laboratory reared eggs collected onboard the RV KayKay with oblique Bongo nets tows in the nearshore waters off Dichato, Chile $\left(36.5^{\circ} \mathrm{S}\right)$ during October 2000. Samples were placed separately in a $4 \mathrm{~L}$ plastic jar inside a cooler with icepacks and immediately 
transported to the Universidad de Concepción, Estación de Biología Marina at Dichato (36 30'S), where early life stages of $N$. crockeri were separated under stereomicroscopes and incubations were carried out. Early stage eggs (i.e., without evidence of embryo) were initially maintained in $1 \mathrm{~L}$ glass jars with ultraviolet-irradiated and filtered seawater $(0.5$ $\mu \mathrm{m})$ inside a water bath at $12^{\circ} \mathrm{C}$ and a photoperiod of 12L:12D. One-third of the seawater was replaced daily. Once hatching occurred, yolk-sac larvae and preflexion larvae were maintained without food until death. Recently hatched larvae $(\mathrm{N}=38)$ were anesthetized and measured under a stereomicroscope and dim light in the Marine Station at Dichato.

\section{OTOLITH MICROSTRUCTURE, LARVAL GROWTH, AND HATCHING DATES}

A total of 90 ethanol-preserved $N$. crockeri larvae were removed from the November $2001(\mathrm{~N}=19,4.0-11.2 \mathrm{~mm}$ larval length) and March 2002 surveys ( $\mathrm{N}=71,5.7-16.0$ $\mathrm{mm}$ larval length). The larvae were placed on a glass slide, with a drop of water, and left and right sagitta otoliths were removed from the larvae using entomological needles. Otoliths were embedded in epoxic resin and analyzed using a microscope and computer image analyzer (Optimas $\AA$ 6.1 software). One measurement of otolith area and three consecutive measurements of otolith diameter were made and the average otolith diameter was calculated for each otolith. Larval otoliths were read at 1000x magnification in immersion oil. Larval lengths were not corrected for shrinkage and it was assumed that otolith increments were deposited daily, as can be observed in several marine fish larvae (Kokita \& Omori 1998, Hernández \& Castro 2000).

Integrated growth of larvae per survey (2001 and 2002 separately) was estimated from the slope of a linear regression by least squares between body size and age: $\mathrm{L}(\mathrm{t})=\alpha+\beta \mathrm{t}$, where $\mathrm{L}(\mathrm{t})=$ larval length $(\mathrm{mm})$ at age $\mathrm{t}$, $\mathrm{t}=$ ring counts, $\beta=$ slope (growth rate, $\mathrm{mm} \mathrm{day}^{-1}$ ), and $\alpha=$ intercept (larval length at hatch, $\mathrm{mm}$ ). To establish if significant differences in larval growth occurred between the two surveys, an ANCOVA test was run (multiple-slope test, Zar 1999). To obtain the $95 \%$ confidence intervals of the estimated parameters, 5000 randomly generated data sets were utilized to determine the frequency distribution of $\alpha$ and $\beta$ for each cruise (Table 3 ), Monte Carlo simulations were used to test differences between the mean values of $\alpha$ and $\beta$ (Table 4).

The hatching period of larvae collected during the surveys carried out in November 2001 and March 2002 were first estimated by obtaining a larval length-at-age key for both sampling periods. The length frequency distribution of larvae at each station was then converted to an age-frequency distribution using the length-at-age key, from which the hatching period was back-calculated. The hatching date distribution for each sampling day from both surveys was weighted according to the standardized abundance of the catch per station, and then summed to obtain the distribution in the population.

\section{Results}

\section{DESCRIPTION OF Normanichthys crockeri EGGS}

Normanichthys crockeri eggs are spherical, measuring $0.75-0.83 \mathrm{~mm}$ in diameter (mean \pm standard deviation, $0.78 \pm 0.04 \mathrm{~mm}, \mathrm{~N}=122$ ). They have homogeneous yolk, narrow perivitelline space, smooth chorion and a single oil globule (0.21-0.26 mm diameter, $0.22 \pm 0.07 \mathrm{~mm}, \mathrm{~N}$ $=122$ ) pigmented in their internal base. Prior to hatch, embryos show puntiform melanophores along the dorsal and caudal region. The proportion between oil globule diameter and egg diameter (oleocapsular ratio, 19-28\%) is a unique feature for the identification of eggs from this species. Fish eggs collected in the same area (central Chile) either don't have oil globules (e.g., sardines, Strangomera bentincki, Ethmidium maculatum, Herrera et al. 1987), have smaller oleocapsular ratios (e.g., Chilean hake, Merluccius gayi, Pacific sandperch Prolatilus jugularis, Fischer 1958, 1959) or have larger egg diameters (e.g., bigeye flounder, Hippoglossina macrops, Landaeta et al. 2006). Development at $12^{\circ} \mathrm{C}$ from the morula stage took up to $48 \mathrm{~h}$ for hatching. After hatching, yolk-sac larvae fed endogenously for 6 days at $12^{\circ} \mathrm{C}$. Preflexion larvae hatched from eggs collected in the field were positively identified for the 1) presence of puntiform melanophores ventrally along the trunk and tail, 2) stellate melanophores in the dorsal zone of the tail, and 3) pigment in the isthmus (Vélez et al. 2003).

\section{SPATIAL DISTRIBUTION OF EARLY LIFE STAGES OF $N$. crockeri}

During the austral spring of 1996 early life stages of $N$. crockeri were collected over the continental shelf of central Chile (Fig. 2). Eggs were found close to shore ( $<12 \mathrm{~km}$ offshore) and associated to headlands in the north part of the study area, such as Carranza cape and inside Gulf of Arauco. Abundance ranged between 1.1 and $89.410 \mathrm{~m}^{-2}$, with the highest abundance collected south of Carranza cape (Table 1). Pre- and postflexion larvae were concentrated over the Itata terrace, particularly off 


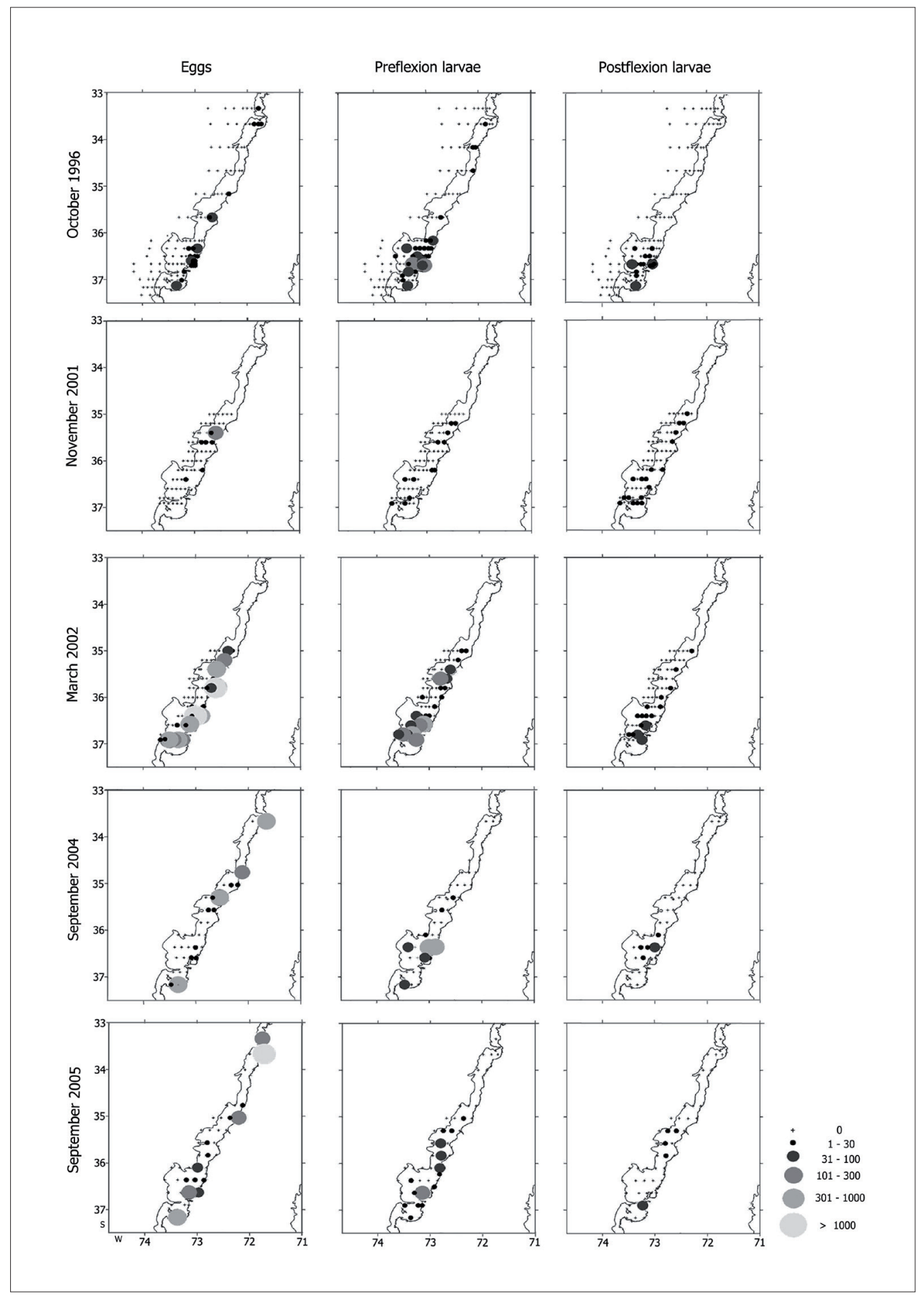

Figure 2. Horizontal distribution of eggs, preflexion larvae and postflexion larvae of $N$. crockeri, off central Chile during October 1996, November 2001, March 2002, September 2004 and 2005. Abundances expressed as individuals $10 \mathrm{~m}^{-2}$ / Distribución horizontal de huevos, larvas en preflexión y larvas en postflexión de $\mathrm{N}$. crockeri, frente a Chile central durante octubre 1996, noviembre 2001, marzo 2002, septiembre 2004 y 2005. Abundancias expresadas como individuos $10 \mathrm{~m}^{-2}$ 
Table 1. Mean abundance (individuals $10 \mathrm{~m}^{-2}$ ), median, standard deviation (SD), maximum values and quartiles of eggs and larvae of $N$. crockeri off central Chile / Abundancia promedio (individuos $10 \mathrm{~m}^{-2}$ ), mediana, desviación estándar (SD), valores máximos y cuartiles de huevos y larvas de $N$. crockeri frente a Chile central

\begin{tabular}{|c|c|c|c|c|c|c|c|c|c|c|c|c|c|c|c|c|c|c|}
\hline \multirow[b]{2}{*}{ Sampling date } & \multicolumn{6}{|c|}{ Eggs } & \multicolumn{6}{|c|}{ Preflexion larvae } & \multicolumn{6}{|c|}{ Postflexion larvae } \\
\hline & Mean & SD & $\operatorname{Max}$ & Median & $\begin{array}{l}\text { Lower } \\
\text { Quartile }\end{array}$ & $\begin{array}{c}\text { Upper } \\
\text { Quartile }\end{array}$ & Mean & SD & $\operatorname{Max}$ & Median & $\begin{array}{l}\text { Lower } \\
\text { Quartile }\end{array}$ & $\begin{array}{l}\text { Upper } \\
\text { Quartile }\end{array}$ & Mean & SD & Max & Median & $\begin{array}{l}\text { Lower } \\
\text { Quartile }\end{array}$ & $\begin{array}{c}\text { Upper } \\
\text { Quartile }\end{array}$ \\
\hline October 1996 & 16.66 & 21.17 & 89.41 & 6.19 & 2.62 & 25.63 & 24.59 & 28.94 & 111.47 & 14.85 & 4.25 & 33.35 & 14.97 & 14.98 & 53.75 & 8.52 & 3.17 & 20.68 \\
\hline November 2001 & 22.06 & 37.18 & 104.64 & 5.64 & 3.98 & 24.48 & 8.64 & 8.94 & 27.24 & 4.52 & 3.50 & 9.58 & 5.79 & 3.65 & 14.13 & 4.29 & 2.94 & 8.06 \\
\hline March 2002 & 788.02 & 2163.73 & 9693.16 & 35.04 & 7.86 & 457.81 & 50.69 & 99.52 & 374.65 & 32.27 & 15.37 & 84.33 & 13.19 & 13.82 & 55.20 & 8.19 & 4.78 & 14.12 \\
\hline September 2004 & 174.57 & 311.88 & 899.00 & 19.33 & 11.68 & 122.82 & 108.03 & 158.47 & 398.45 & 35.63 & 9.23 & 81.10 & 31.23 & 36.75 & 96.32 & 17.89 & 11.39 & 21.80 \\
\hline September 2005 & 158.77 & 325.23 & 1240.88 & 29.16 & 11.17 & 109.51 & 31.96 & 52.80 & 210.59 & 10.47 & 6.22 & 35.72 & 18.43 & 17.11 & 47.15 & 11.17 & 8.13 & 20.78 \\
\hline
\end{tabular}

Talcahuano (maximum value, 111.5 preflexion larvae $10 \mathrm{~m}^{-2}, 53.7$ postflexion larvae $10 \mathrm{~m}^{-2}$ ), with decreased abundance of larvae $\left(<1010 \mathrm{~m}^{-2}\right)$ in the northern part of the study area.

Few eggs and larvae were collected over the shelf during November 2001 (austral spring). Off Carranza cape egg abundance was $104.610 \mathrm{~m}^{-2}$, but in the rest of the study area egg abundance ranged between 3.9 and 24.5 $10 \mathrm{~m}^{-2}$ (Fig. 2). Larval abundance was low throughout the continental shelf, with mean values $( \pm$ one standard deviation, SD) of $8.6 \pm 8.910 \mathrm{~m}^{-2}$ and $5.8 \pm 3.610 \mathrm{~m}^{-2}$ for pre- and postflexion larvae, respectively (Table 1).

During the austral late summer of 2002 (March) large numbers of eggs were collected in coastal waters off central Chile (Fig. 2). Mean density of $N$. crockeri eggs was $788 \pm$ $2163.710 \mathrm{~m}^{-2}$, with the highest abundance found south of Carranza cape (9693 $10 \mathrm{~m}^{-2}$ ) and off Talcahuano (4628 10 $\mathrm{m}^{-2}$ ) (Table 1). North of Itata canyon, pre- and postflexion larvae were found mainly in nearshore waters, but over the Itata terrace larvae were collected throughout the shelf and inside of the Gulf of Arauco. Larval abundance varied from 1.6 to $607.310 \mathrm{~m}^{-2}$ (preflexion larvae) and from 0.5 to $55.210 \mathrm{~m}^{-2}$ (postflexion larvae) (Fig. 2).

During the late winter of 2004, coastal spawning was patchy (Fig. 2). Large numbers of eggs were collected off San Antonio (899 $10 \mathrm{~m}^{-2}$ ), north of Carranza cape $\left(80710 \mathrm{~m}^{-2}\right)$, and inside the Gulf of Arauco (461 $\left.10 \mathrm{~m}^{-2}\right)$. However, larvae were found almost exclusively over the Itata terrace (Fig. 2). Mean larval abundance was $108.0 \pm$ 158.5 preflexion larvae $10 \mathrm{~m}^{-2}$ and $31.2 \pm 36.8$ postflexion larvae $10 \mathrm{~m}^{-2}$ (Table 1). Similarly, during late winter in 2005, N. crockeri spawning was concentrated off San Antonio (1240.9 eggs $10 \mathrm{~m}^{-2}$ ) and inside Gulf of Arauco (496.8 eggs $10 \mathrm{~m}^{-2}$ ) (Fig. 2). Preflexion larvae were located over the shelf, mainly in nearshore waters off Talcahuano $\left(210.610 \mathrm{~m}^{-2}\right)$. Compared to smaller larvae, postflexion larvae were scarce, ranging between 4.9 and $47.110 \mathrm{~m}^{-2}$ (Fig. 2).
Analysis of vertically stratified samples showed that eggs and larvae were found mainly in the upper $50 \mathrm{~m}$ of the water column throughout their early development (Fig. 3). During the austral spring of 1996 two strata were sampled (0-40 and 40-100 m depth) and early stages were more recurrent in the shallower surface stratum. However, significant differences in depth distribution were only detected for preflexion larvae (Mann-Whitney $\mathrm{U}$ test, $\mathrm{U}=$ $107, P<0.001)$. Eggs and postflexion larvae did not show significant differences between depth strata (eggs: $U=29$, $P=0.16$, postflexion larvae: $\mathrm{U}=30, P=0.40$ ). Although sampling was carried out to $250 \mathrm{~m}$ depth during November 2001, eggs were restricted to the top $50 \mathrm{~m}$ and larvae were present from $100 \mathrm{~m}$ to surface (Fig. 3). The highest densities of pre- and postflexion larvae were obtained in the mixed layer (240 preflexion larvae $1000 \mathrm{~m}^{-3}$ at $0-10$ $\mathrm{m}$ depth; 48 postflexion larvae $1000 \mathrm{~m}^{-3}$ at $0-25 \mathrm{~m}$ depth).

A similar trend was observed during March 2002, when early life stages were predominantly found in the upper 50 $\mathrm{m}$ (Fig. 3). The largest densities of eggs and larvae were collected in surface waters $\left(\sim 92,000\right.$ eggs $1000 \mathrm{~m}^{-3}$ at $0-10$ $\mathrm{m}, 4674$ preflexion larvae $1000 \mathrm{~m}^{-3}$ at $0-25 \mathrm{~m}$, and 326 postflexion larvae $1000 \mathrm{~m}^{-3}$ at $0-25 \mathrm{~m}$ ).

Table 2 summarizes the results obtained for the estimation of the centroid depth distribution of preand postflexion larvae during the cruises carried out in November 2001 and March 2002 off central Chile. During spring 2001, larvae smaller than $7 \mathrm{~mm}$ NL were widely distributed in the water column during the day, but were restricted to the shallowest depth strata (mean depth $=13 \mathrm{~m}$ ) at night; however, no significant differences were detected in the depth distribution $(\mathrm{U}=6, P=0.09)$. Postflexion larvae were distributed at similar depths, and their centroid depths were located near the pycnocline with no significant differences in depth distribution detected $(\mathrm{U}=26.5, P=0.50)$. During March 2002, preand postflexion larvae were homogenously distributed during day and night, and the centroid depths were located 
Table 2. Basic statistics of the centroid depth distribution (CDD, in $\mathrm{m}$ ) of pre and postflexion larvae of $N$. crockeri during November 2001 and March 2002 off central Chile. SD = standard deviation / Estadísticas básicas de la distribución de profundidad del centroide (CDD, en $\mathrm{m}$ ) de larvas en pre y postflexión de $\mathrm{N}$. crockeri durante noviembre de 2001 y marzo de 2002 frente a Chile central. SD = desviación estándar

\begin{tabular}{|c|c|c|c|c|c|c|c|c|}
\hline & \multicolumn{4}{|c|}{ November 2001} & \multicolumn{4}{|c|}{ March 2002} \\
\hline & \multicolumn{2}{|c|}{ Preflexion } & \multicolumn{2}{|c|}{ Postflexion } & \multicolumn{2}{|c|}{ Preflexion } & \multicolumn{2}{|c|}{ Postflexion } \\
\hline & $\begin{array}{c}\text { Day } \\
(n=8)\end{array}$ & $\begin{array}{l}\text { Night } \\
(n=4)\end{array}$ & $\begin{array}{c}\text { Day } \\
(n=11)\end{array}$ & $\begin{array}{c}\text { Night } \\
(n=6)\end{array}$ & $\begin{array}{c}\text { Day } \\
(n=27)\end{array}$ & $\begin{array}{c}\text { Night } \\
(n=16)\end{array}$ & $\begin{array}{c}\text { Day } \\
(n=14)\end{array}$ & $\begin{array}{l}\text { Night } \\
(n=9)\end{array}$ \\
\hline Minimum & 6.08 & 13.00 & 18.00 & 16.53 & 13.00 & 13.00 & 13.00 & 13.00 \\
\hline Maximum & 75.00 & 13.00 & 52.19 & 63.00 & 38.00 & 38.00 & 38.00 & 38.92 \\
\hline Mean & 34.93 & 13.00 & 36.84 & 43.69 & 21.43 & 22.04 & 24.11 & 20.67 \\
\hline $\mathrm{SD}$ & 21.79 & - & 10.53 & 22.44 & 14.05 & 8.51 & 11.40 & 9.97 \\
\hline
\end{tabular}

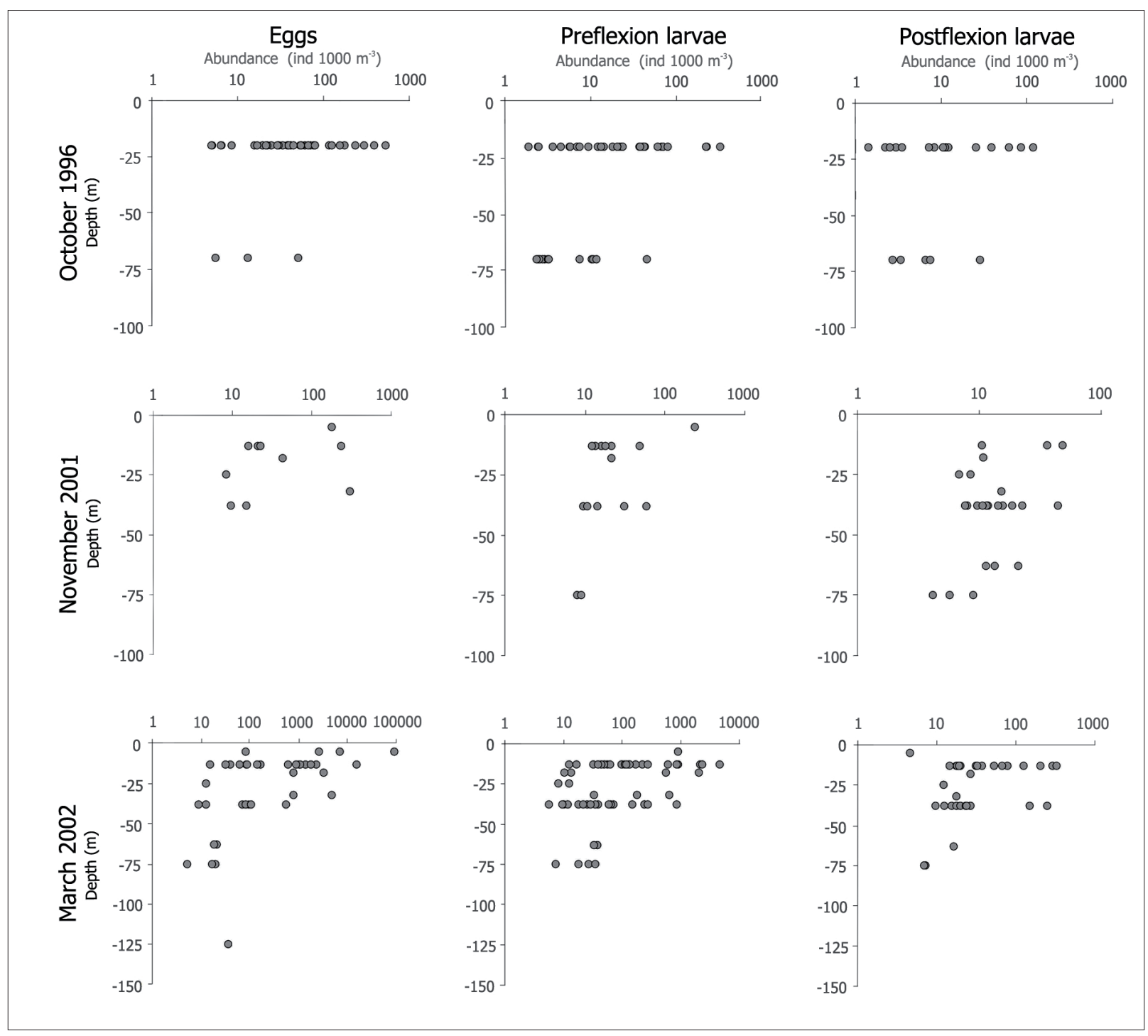

Figure 3. Vertical distribution of eggs and larvae of $N$. crockeri off central Chile during October 1996, November 2001 and March 2002. Abundances expressed as individuals $1000 \mathrm{~m}^{-3} ; \mathrm{x}$-axis in log scale / Distribución vertical de huevos y larvas de $\mathrm{N}$. crockeri frente a Chile central durante octubre de 1996, noviembre de 2001 y marzo de 2002 . Abundancias expresadas como individuos $1000 \mathrm{~m}^{-3}$; eje $\mathrm{x}$ en escala logarítmica 
Table 3. Linear regression models $(L L=a+B * A)$ fitted to larval growth of wild-caught $N$. crockeri off central Chile during November 2001 and March 2002. LL = larval length $(\mathrm{mm}), \mathrm{A}=$ age (number of otolith increments), $\mathrm{Cl}=$ confidence intervals / Modelos de regresión lineal $(L L=a+B * A)$ ajustados al crecimiento larval de $N$. crockeri capturados frente a Chile central durante noviembre de 2001 y marzo de 2002. $\mathrm{LL}=$ longitud larval $(\mathrm{mm}), \mathrm{A}=$ edad (número de incrementos de otolitos), $\mathrm{Cl}=$ intervalos de confianza

\begin{tabular}{lcccccccc}
\hline Sampling date & $\mathrm{N}$ & Parameter & $\begin{array}{c}\text { Best-fit } \\
\text { value }\end{array}$ & $\begin{array}{c}\text { Standard } \\
\text { Error }\end{array}$ & CI lower & CI upper & $P$-value & $\mathrm{r}^{2}$ \\
\hline November 2001 & \multirow{2}{*}{19} & $\alpha$ & 2.866 & 0.3118 & 2.2079 & 3.5236 & $<0.05$ & 0.90 \\
& & $\beta$ & 0.201 & 0.0161 & 0.1673 & 0.2354 & $<0.05$ & $<0.05$ \\
March 2002 & \multirow{2}{*}{71} & $\alpha$ & 3.934 & 0.2877 & 3.3607 & 4.5081 & 0.89 \\
& & $\beta$ & 0.151 & 0.0061 & 0.1386 & 0.1629 & $<0.05$ & \\
\hline
\end{tabular}

between 20 and $24 \mathrm{~m}$ for all cases, with no significant diel differences detected (preflexion larvae: $\mathrm{U}=136.5, P=$ 0.43 ; postflexion larvae: $\mathrm{U}=52, P=0.49$ ).

Figure 4 shows the spatial distribution of eggs, preflexion (larvae $<7 \mathrm{~mm} \mathrm{NL}$ ) and postflexion (larvae $>7$ $\mathrm{mm} \mathrm{SL}$ ) larvae during two phases of an upwelling cycle, at relaxation (November 2001) and at the beginning of an upwelling event (March 2002). During relaxation, there was strong stratification across the shelf, with a mixed layer of warmer $\left(>11^{\circ} \mathrm{C}\right)$ and less salty $(<34.3)$ waters to $50 \mathrm{~m}$ depth, and a denser deep layer ( $>26.4$ units of sigma-t). Under this oceanographic setting, eggs and larvae were restricted to nearshore and surface waters of the continental shelf off central Chile (Fig. 4).

In the Gulf of Arauco during March of 2002, there was a coastal ascent of a $12^{\circ} \mathrm{C}$ isotherm and a 34.4 isohaline (Fig. 4). Eggs and larvae were located throughout the Gulf in the upper $25 \mathrm{~m}\left(>3001000 \mathrm{~m}^{-3}\right)$, but they were found in higher abundance in nearshore waters with few collected in deeper and denser waters $\left(<301000 \mathrm{~m}^{-3}\right)$.

\section{Temporal Distribution OF EGGS AND LARVAE OF Normanichthys crockeri IN COASTAL WATERS}

The coastal time series of eggs and larvae of $N$. crockeri off the Talcahuano area showed peaks of abundance mainly during the mid and late summer months (January, March and April) (Fig. 5). Maximum egg abundances occurred in April $2005\left(338.5 \pm 289.110 \mathrm{~m}^{-2}\right)$ and January 2006 $\left(123.9 \pm 175.210 \mathrm{~m}^{-2}\right)$ (Fig. 5a). On the other hand, larvae were collected in higher abundance and frequency almost exclusively between August and November 2004, with a peak during August $2004\left(11.2 \pm 11.410 \mathrm{~m}^{-2}\right)$ and August $2005\left(20.3 \pm 37.210 \mathrm{~m}^{-2}\right)$. Decreased larval abundances were observed in the following months during the austral spring of 2005 and early autumn of 2006 (Fig. 5b).

\section{LARVAL LENGTH DISTRIBUTION, GROWTH AND HATCHING DATE}

Larval length frequency distribution differed between collections carried out during November 2001 and March 2002 (Fig. 6). In spring 2001, larvae collected in the zooplankton samples ranged between 3.38 and $18.83 \mathrm{~mm}$ (mean $=8.25 \mathrm{~mm}, \mathrm{SD}=3.51$ ) with most of the larvae at the postflexion stage. On the other hand, larvae collected during late summer had a shorter length range, varying from 2.00 to $13.24 \mathrm{~mm}($ mean $=5.15 \mathrm{~mm}, \mathrm{SD}=1.75)$, with most of them at the preflexion stage (Fig. 6).

Otolith microstructure analysis from larvae collected in the wild showed significant relationships between otolith size and larval length (Fig. 7a, b). Pooling together the data from both cruises, a linear regression described the relationship between otolith diameter (OD, in $\mu \mathrm{m})$ and larval length (LL, in mm), OD = $24.2(\mathrm{LL})-80.2\left(\mathrm{r}^{2}=\right.$ $0.95, \mathrm{n}=90, P<0.001$ ) (Fig. 7a). Similarly, a power model explain the relationship between otolith area (OA, in $\left.\mu \mathrm{m}^{2}\right)$ and larval length, $\mathrm{OA}=5.5(\mathrm{LL})^{3.5}\left(\mathrm{r}^{2}=0.92, \mathrm{n}=\right.$ 90, $P<0.001$ ) (Fig. 7b). These results indicate that otolith growth may be a good predictor of somatic growth.

The number of microincrements in otoliths of ethanolpreserved larvae of $N$. crockeri collected during November 2001 and March 2002 ranged between 7 and 37, and from 14 to 80 , respectively. Linear regression models were estimated separately for both surveys (Table 3 ) and then compared. However, no significant differences were detected between slopes (i.e., growth rates between 0.15 and $0.20 \mathrm{~mm} \mathrm{day}^{-1}$ ) of both regressions (ANCOVA, $\mathrm{F}=$ $0.11, P=0.74)$. Therefore, all data were pooled together, and the intercept ( $a$ parameter in the linear regression) was fixed at $2.7 \mathrm{~mm}$, the mean larval size at hatch. The linear model yielded a daily growth rate of $0.16 \mathrm{~mm} \mathrm{day}^{-1}(\mathrm{~N}=$ $\left.90, \mathrm{r}^{2}=0.93, P<0.01\right)$ (Fig. 7c). 


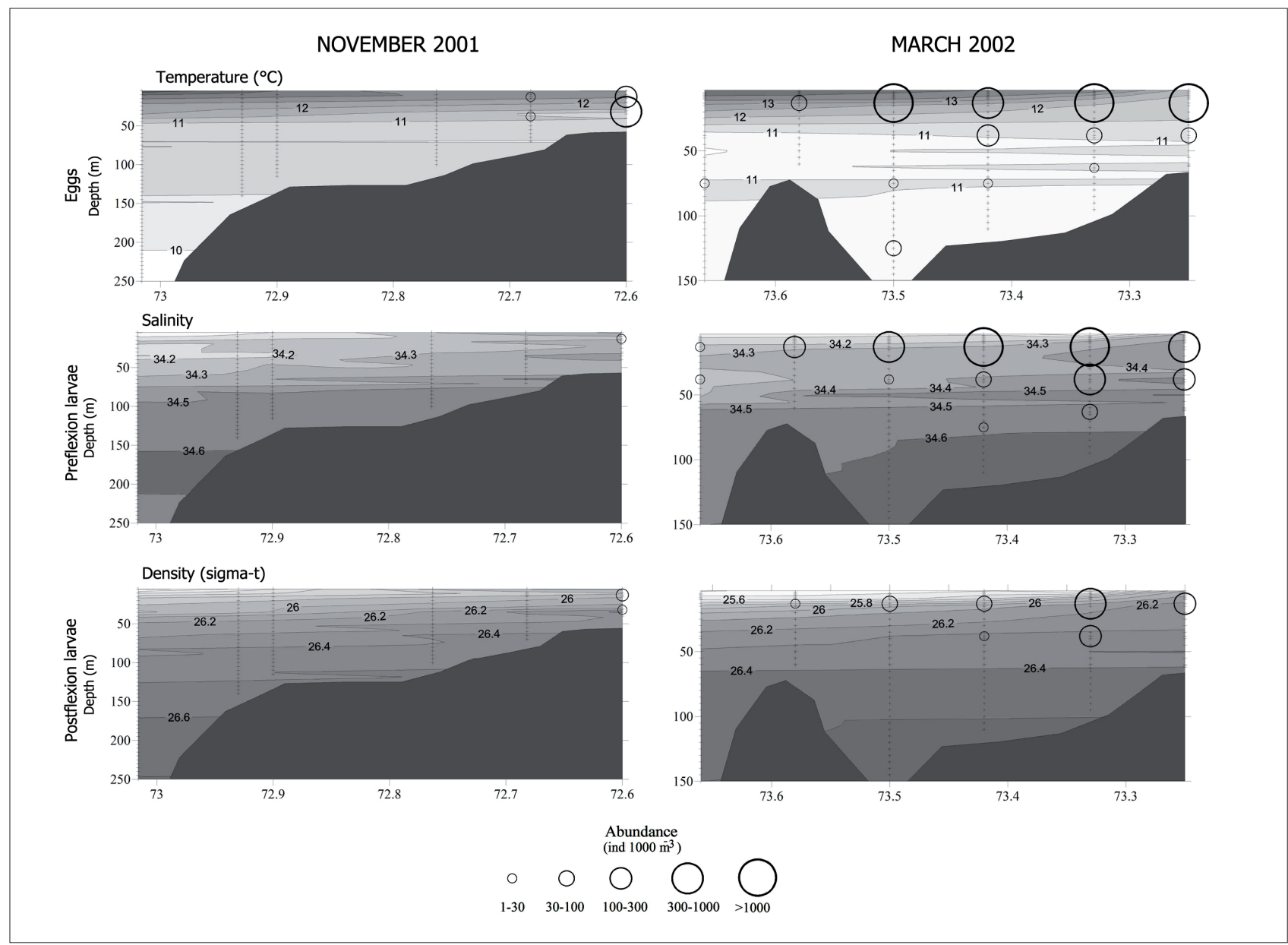

Figure 4. Across-shelf vertical sections of temperature $\left({ }^{\circ} \mathrm{C}\right)$, salinity and density (units of sigma-t) showing two phases of an upwelling cycle: relaxation (November 2001) and the start of an upwelling event (March 2002). Crosses indicate the location and depth of CTD casts. Overlayed are the vertical distribution of eggs, pre- and postflexion larvae, with abundances expressed as individuals $1000 \mathrm{~m}^{-3}$. Left section located at $35^{\circ} 25^{\prime} \mathrm{S}$; right section located at $37^{\circ} \mathrm{S} /$ Secciones verticales a lo ancho de la plataforma continental de temperatura $\left({ }^{\circ} \mathrm{C}\right.$ ), salinidad y densidad (unidades de sigma-t) mostrando dos fases de un ciclo de surgencia: relajación (noviembre de 2001) y el comienzo de un evento de surgencia (marzo de 2002). Las cruces indican la ubicación y profundidad de los lances de CTD. Superpuesta se encuentra la distribución vertical de huevos, larvas en pre y postflexión, con abundancias expresadas como individuos $1000 \mathrm{~m}^{-3}$. La sección de la izquierda está ubicada a $35^{\circ} 25^{\prime} \mathrm{S}$; la sección de la derecha se ubica a $37^{\circ} \mathrm{S}$

Hatching period estimated from August 2001 (mid winter) to March 2002 (late summer) (Fig. 8) showed a peak during late austral summer (February and March 2002, 3659 and $20291000 \mathrm{~m}^{-3}$, respectively) with few hatching events during late winter and spring $2001(<650$ $1000 \mathrm{~m}^{-3}$ ) (Fig. 8).

\section{Discussion}

There are similarities and differences in the early life history of N. crockeri and the reproductive tactics of other small pelagic fishes inhabiting the Humboldt upwelling ecosystem. Like several species of schooling fishes in the area, reproductive events are carried out in protected shallow waters and eggs and larvae are found in surface nearshore waters where they may benefit from retention and enrichment processes (Bakun 1996, Lett et al. 2007). Anchoveta (Engraulis ringens) and common sardine (Strangomera bentincki) reproduce inside bays, gulfs and near estuaries off central Chile mainly during austral winter season (Castro et al. 2000, Cubillos et al. 2001, 2007, Vargas et al. 2003) and occasionally during summer (Lett et al. 2007).

Previous ichthyoplankton studies in the Humboldt ecosystem have collected preflexion larvae of $N$. crockeri inside bays off Perú mainly during austral spring (up to $47001000 \mathrm{~m}^{-3}$, Vélez et al. 2005) and close to shore off 


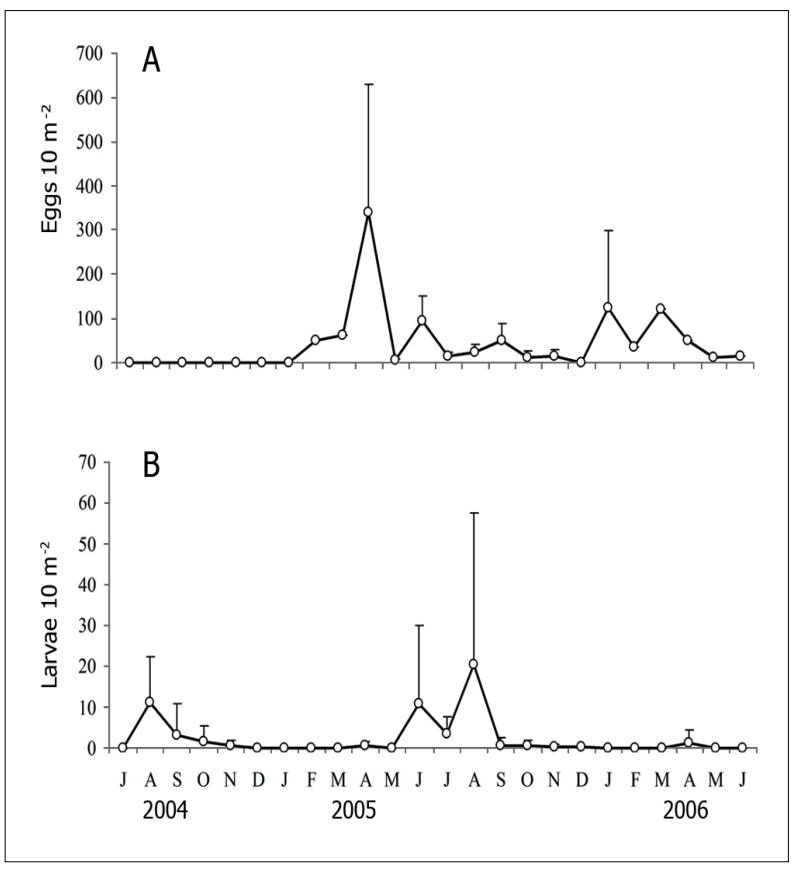

Figure 5. Coastal time series of A) eggs and B) larval abundance (individual $10 \mathrm{~m}^{-2}$ ) of $\mathrm{N}$. crockeri off Talcahuano, central Chile between July 2004 and June 2006 / Serie de tiempo costera de abundancia de A) huevos y B) larvas (individuos $10 \mathrm{~m}^{-2}$ ) de N. crockeri frente a Talcahuano, Chile central entre julio 2004 y junio 2006

central Chile during late winter, spring and summer (up to $501000 \mathrm{~m}^{-3}$, Castro et al. 2000, Hernández-Miranda et al. 2003, Landaeta et al. 2008). Our results showed that higher abundances of $N$. crockeri eggs were collected during transitional periods such as late winter and late summer and, in a lesser extent, during spring (Table 1, Fig. 5). The transitional periods (from winter to spring, from summer to autumn) off central Chile are characterized by strong changes in wind speed and direction (Arcos \& Navarro 1986, Parada et al. 2001), which affect the incidence of relaxation and upwelling events. This variability reduces the offshore Ekman transport of surface waters and there is an increase of the anticlockwise vorticity, increasing the retention of nearshore water parcels (Sobarzo et al. 2007) and the zooplankton contained in the surface water column. Since most eggs and larvae of $N$. crockeri are located in the top $50 \mathrm{~m}$ of the water column (Fig. 3), where the surface Ekman layer has been estimated (Sobarzo et al. 2001), spawning processes occurring during transitional periods may increase the coastal retention of eggs and larvae of N. crockeri, especially when the spawning occurs inside bays (Landaeta \& Castro 2006b).

On the other hand, during austral spring and summer south-westerly winds lead to the offshore transport of surface waters resulting in the upwelling of cold, deep water in coastal waters. Spawning near capes during the upwelling season (austral spring and summer) may increase the chance of coastal retention of eggs and larvae that occur between the upwelling front and headlands (i.e., in an upwelling shadow, Graham et al. 1992, Wing et al. 1998, Marín et al. 2003). Such retention has been observed in several marine species with meroplanktonic larvae that settle near the coast in upwelling systems (gastropod Concholepas concholepas, Poulin et al. 2002, crabs Emerita analoga and Neotrypaea uncinata, Yannicelli et al. 2006a, Paraxanthus barbiger, Palma et al. 2006, fishes Sebastes spp. Wing et al. 1998, Bjorkstedt et al. 2002). This physical mechanism may explain the horizontal distribution of early stages of the $N$. crockeri off central Chile during austral spring 1996 and 2001 (Fig. 2). In this sense, the coastal geometry may play a role in the maintenance, growth and survival of planktonic stages of $N$. crockeri throughout their early ontogeny in nearshore surface waters (Fig. 3 and 4). At a scale of 100 's m to few kilometers, peninsular sites protected from southerly winds (favorable for upwelling) are vertically more stratified and promote the increment

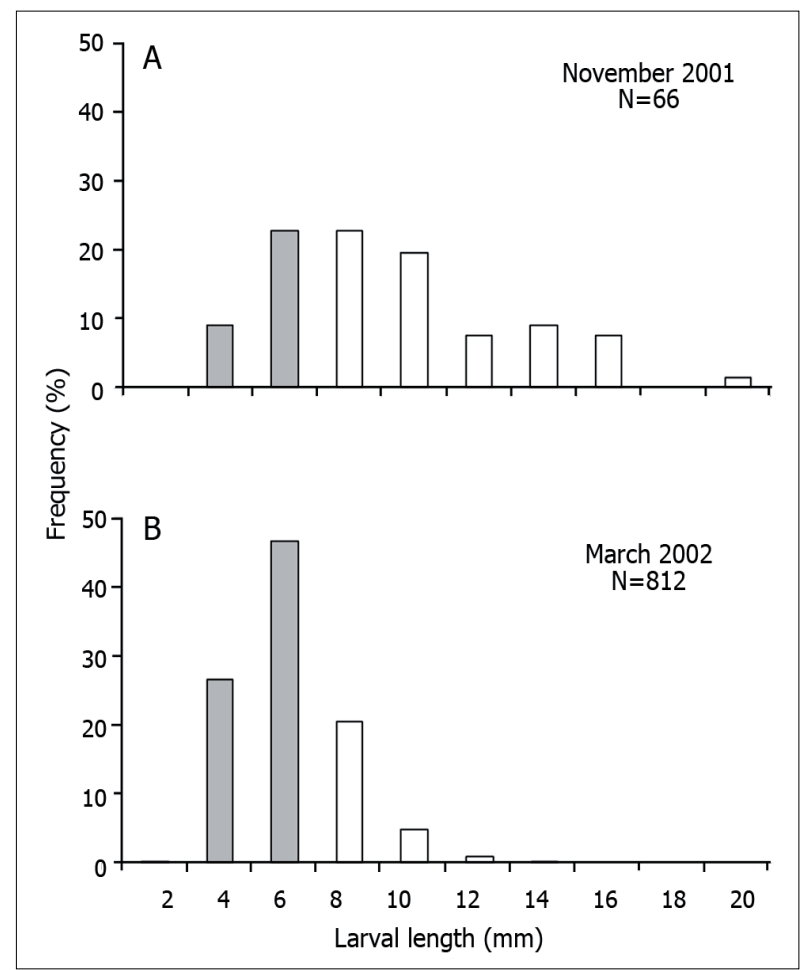

Figure 6. Larval size distribution of $N$. crockeri collected during A) November 2001 and B) March 2002, off central Chile. Grey bars indicate preflexion larvae / Distribución de tamaño de larvas de $N$. crockeri recolectadas durante A) noviembre 2001 y B) marzo 2002, frente a Chile central. Las barras grises indican larvas en preflexión 


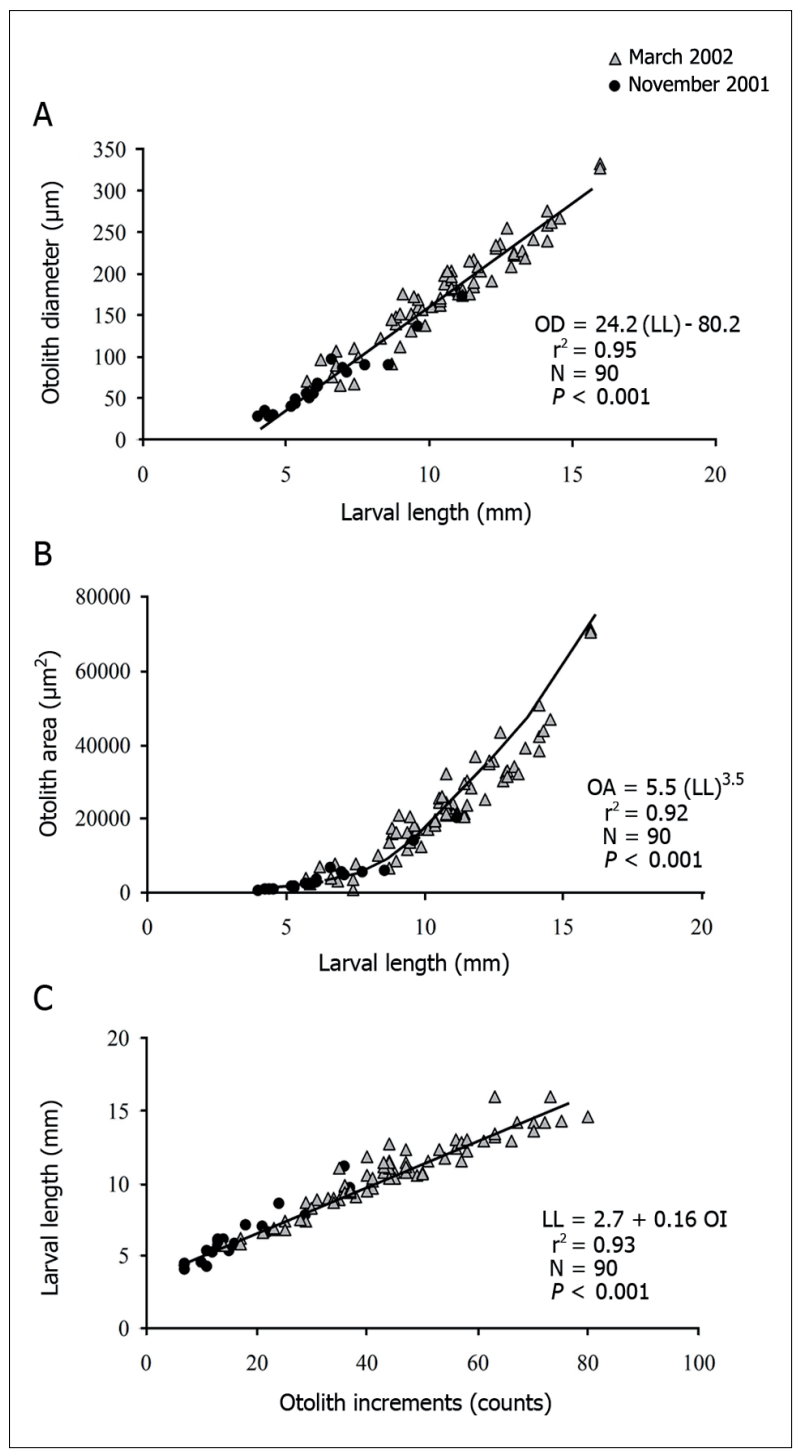

Figure 7. Relationships $N$. crockeri larval length (LL, $\mathrm{mm}$ ) with A) otolith diameter $(\mathrm{OD}, \mu \mathrm{m}), \mathrm{B})$ otolith area $\left(\mathrm{OA}, \mu \mathrm{m}^{2}\right)$, and $\left.\mathrm{C}\right)$ number of otolith ring counts $(\mathrm{OI})$. The slope of the least-squares linear regression corresponds to the larval growth rate $\left(\mathrm{mm} \mathrm{day}^{-1}\right)$ / Relaciones entre la longitud larval de N. crockeri (LL, $\mathrm{mm}$ ) con A) diámetro del otolito $(\mathrm{OD}, \mu \mathrm{m}), \mathrm{B})$ área del otolito $\left(\mathrm{OA}, \mu \mathrm{m}^{2}\right)$ y C) número de conteos de anillos en otolitos (OI). La pendiente de la regresión lineal por mínimos cuadrados corresponde a la tasa de crecimiento larval ( $m m$ día $^{-1}$ )

of phytoplankton biomass, high concentration of primary production and the retention and settlement/recruitment of meroplankton (Palma et al. 2006, Henríquez et al. 2007). Although more recently an opposite pattern has been described whereas the weakening of upwellingfavorable winds favors the retention, along exposed sides of small headlands, of phytoplankton and associated primary production (Palma et al. 2009). Since larvae of

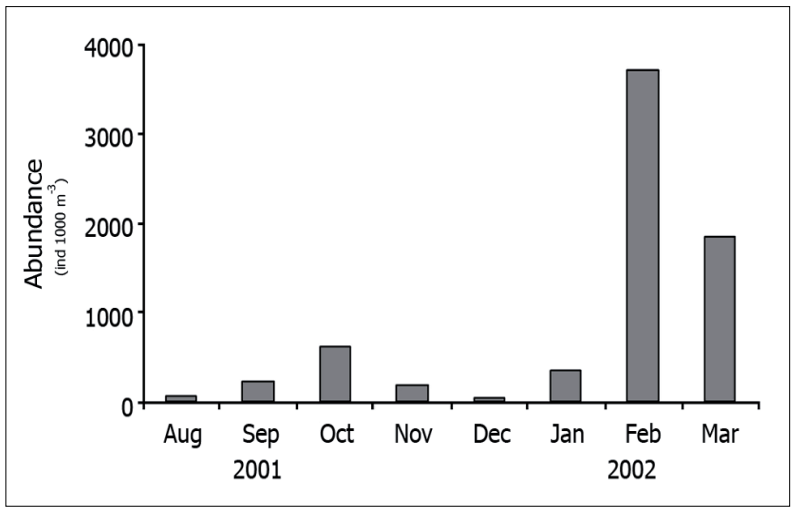

Figure 8. Back-calculated hatching date estimates of $N$. crockeri off central Chile based on otolith ring counts. Abundance of hatched larvae expressed as individuals $1000 \mathrm{~m}^{-3} /$ Fechas de eclosión retrocalculadas de $N$. crockeri frente a Chile central basadas en conteo de anillo de otolitos. La abundancia de las larvas eclosionadas se expresa en individuos $1000 \mathrm{~m}^{-3}$

$N$. crockeri are vertically distributed in surface waters and feed on microplankton (mostly copepod eggs, copepods and tintinids, Balbontín et al. 1997), protected sites around headlands along central Chile are optimal locations where the feeding success and larval growth of $N$. crockeri can occur.

Although no diel vertical migration of larvae was detected in our analysis (Table 2), this behaviour should not be discarded. Probably the sampled strata in our study were too broad to detect the variability of larval $N$. crockeri in the vertical plane. Some zooplankters, such as the copepods Calanoides patagoniensis and Calanus chilensis, show vertical oscillations at a fine scale (between 10 and $30 \mathrm{~m}$ depth) off central Chile (Castro et al. 2007). Therefore, this topic needs to be addressed in the future, particularly in relation to physical processes occurring in coastal waters, such as sea breeze and tidal forcing (Yannicelli et al. 2006b).

The lack of recently hatched larvae in the field samples may be due to extrusion from the nets, particularly for the Tucker trawl. Although Vélez et al. (2003) collected larvae as small as $1.8 \mathrm{~mm}$ LL by using Bongo nets of 0.333 $\mu \mathrm{m}$ mesh size, the towing speed and the lower capture efficiency of the Tucker trawl for larvae smaller than $5 \mathrm{~mm}$ (Pepin \& Shears 1997) may have affected the estimated abundances of larval $N$. crockeri during November 2001 and March 2002.

In relation to the otolith microstructure and growth, larvae of $N$. crockeri showed lower growth rates than those of other small pelagic fishes with slender larvae inhabiting upwelling ecosystems. Otolith-based estimations of larval 
Table 4. Monte Carlo simulations $(\mathrm{N}=5000)$ for the comparison of the mean values of the growth parameters for larval $N$. crockeri / Simulaciones Monte Carlo $(\mathrm{N}=5000)$ para la comparación de los valores promedio de los parámetros de crecimiento en larvas de N. crockeri

\begin{tabular}{lcccc}
\hline & \multicolumn{2}{c}{$A$} & \multicolumn{2}{c}{$\beta$} \\
& 2001 & 2002 & 2001 & 2002 \\
\hline $\mathrm{N}$ & 5000 & 5000 & 5000 & 5000 \\
Estimated mean & 2.874 & 3.93 & 0.201 & 0.15 \\
$S^{2} P$ & 0.07568 & & 0.00015 & \\
$t_{\text {cal }}$ & -191.86 & & 208.29 & \\
$P$ - value & $>0.05$ & & $>0.05$ & \\
\hline
\end{tabular}

growth of anchoveta (E. ringens, $0.66 \mathrm{~mm} \mathrm{day}^{-1}$, Herrera et al. 1985, $0.47 \mathrm{~mm}_{\text {day }}{ }^{-1}$, Hernández \& Castro 2000, 0.68$0.79 \mathrm{~mm}$ day $^{-1}$ Castro \& Hernández 2000), common sardine (S. bentincki, $0.38 \mathrm{~mm} \mathrm{day}^{-1}$, Castro et al. 1997) and sardine (Sardinops sagax, 0.40-0.65 mm day ${ }^{-1}$, Castillo et al. 1985) off central Chile where higher than estimates for $N$. crockeri larvae $\left(0.15-0.20 \mathrm{~mm} \mathrm{day}^{-1}\right)$. Growth estimates of larval $N$. crockeri were more similar to other fish species with deeper bodied larva such as rockfish (Sebastes saxicola, $0.13 \mathrm{~mm} \mathrm{day}^{-1}$, Laidig et al. 1996; S. goodie, $0.14 \mathrm{~mm}$ day $^{-1}$, Sakuma \& Laidig 1995; S. jordani, $0.17 \mathrm{~mm}^{\text {day }}{ }^{-1}$, Laidig et al. 1991; S. oculatus, $0.15 \mathrm{~mm} \mathrm{day}^{-1}$, Landaeta $\&$ Castro 2006c) and hake (Merluccius productus, 0.16 mm day ${ }^{-1}$, Bailey 1982; M. bilinearis, 0.17-0.18 mm day ${ }^{-1}$, Jeffrey \& Taggartt 2000; M. hubbsi, $0.16 \mathrm{~mm}$ day $^{-1}$, Brown et al. 2004), which also have relatively slow growth rates. The slow growth rate observed in $N$. crockeri larvae seems intriguing considering that is a short-lived species (up to 4 years old, G.A. Aedo, pers. comm. ${ }^{1}$ ); probably for this species larval length is not the best predictor of body growth. According to Vélez et al. (2003), the body depth of $N$. crockeri preflexion larvae is $13 \%$ body length (BL), increasing to $19 \% \mathrm{BL}$ in the transformation stage. Therefore, during postflexion stage, individuals grow more in depth than in length.

In summary, our results indicate that $N$. crockeri off central Chile spawn in coastal protected sites mostly during transitional periods, eggs and larvae are located in the top $50 \mathrm{~m}$ of the water column, and larvae grow at a rate of $0.15-0.20 \mathrm{~mm}$ day $^{-1}$.

Finally, it is important to understand the reproduction and larval ecology of $N$. crockeri due to the increase in landings of this species in recent years as part of the by-catch of the anchoveta and common sardine artisan fisheries. Increased early life history knowledge, will assist in the sustainable management of exploited populations that inhabit the coastal waters of central Chile.

\section{ACKnowledgments}

Authors want to thank two anonymous referees, and to C.A. Bustos, R. Veas, B. Yannicelli, M.C. Krautz for their help in field and laboratory work and for their comments and suggestions on an early version of the manuscript. The cruises were funded by Chilean Fisheries Investigation Funds (FIP 96-11, 2004-03, 2005-02 and 2005-36) and FONDECYT 1010900. This manuscript was partially funded by FONDECYT 11090020 and project MECESUP UVA 06-04.

\section{LITERATURE CITED}

Arcos DF \& N Navarro. 1986. Análisis de un índice de surgencia para la zona de Talcahuano, Chile. Investigación Pesquera 33: 91-98.

Bailey KM. 1982. The early life history of the Pacific hake, Merluccius productus. Fishery Bulletin 80: 589-598.

Bakun A. 1996. Patterns in the ocean. Ocean processes and marine population dynamics, $323 \mathrm{pp}$. California Sea Grant \& Centro de Investigaciones Biológicas del Noroeste, La Paz.

Balbontín F \& R Pérez. 1980. Descripción de los estados larvales de Normanichthys crockeri Clark (Perciformes: Normanichthydae) del área de Valparaíso, Chile. Revista de Biología Marina 17: 81-95.

Balbontín F, A Llanos \& V Valenzuela. 1997. Trophic overlap and feeding incidence of fish larvae from central Chile. Revista Chilena de Historia Natural 70: 381-390.

Barange M, JC Coetzee \& NM Twatwa. 2005. Strategies of space occupation in anchovy and sardine in the southern Benguela: the role of stock size and intra-species competition. ICES Journal of Marine Science 62: 645-654.

Bjorkstedt EP, LK Rosenfield, BA Grantham, Y Shkedy \& J Roughgarden. 2002. Distributions of larval rockfishes Sebastes spp. across nearshore fronts in a coastal upwelling region. Marine Ecology Progress Series 242: 215-228.

Brown DR, E Leonarduzzi \& L Machinandiarena. 2004. Age, growth and mortality of hake larvae (Merluccius hubbsi) in the north Patagonian shelf. Scientia Marina 68: 273-283.

Bustos CA, MF Landaeta \& F Balbontín. 2008. Efectos ambientales sobre la variabilidad espacial del ictioplancton de Chile austral durante noviembre de 2005. Revista Chilena de Historia Natural 81: 205-219.

Castillo G, E Aguilera, G Herrera, PA Bernal, JL Butler, J Chong, H González, C Oyarzún \& C Veloso. 1985. Larval growth rates of the Pacific sardine Sardinops sagax off central Chile, determined by count of daily rings in otoliths. Biología Pesquera 14: 3-10. 
Castro LR \& EH Hernández. 2000. Early life survival of the anchoveta Engraulis ringens off central Chile during the 1995 and 1996 winter spawning seasons. Transactions of the American Fisheries Society 129: 1107-1117.

Castro LR, R Salinas \& EH Hernández. 2000. Environmental influences on winter spawning of the anchoveta Engraulis ringens off central Chile. Marine Ecology Progress Series 197: 247-258.

Castro LR, VA Troncoso \& DR Figueroa. 2007. Fine-scale vertical distribution of coastal and offshore copepods in the Golfo de Arauco, central Chile, during the upwelling season. Progress in Oceanography 75: 486-500.

Castro LR, R Quiñones, H Arancibia, D Figueroa, R Roa, M Sobarzo \& M Retamal. 1997. Áreas de desove de anchoveta y sardina común en la zona central. Final Report Project FIP 96-11, 235 pp. [on line] <http://www.fip.cl/FIP/ Archivos/pdf/informes/IT\%2096-11.pdf >.

Cubillos LA, DF Arcos, DA Bucarey \& MT Canales. 2001. Seasonal growth of small pelagic fish off Talcahuano, Chile $\left(37^{\circ} \mathrm{S}, 73^{\circ} \mathrm{W}\right)$ : a consequence of their reproductive strategy to seasonal upwelling? Aquatic Living Resources 14: 115124.

Cubillos LA, P Ruiz, G Claramunt, S Gacitúa, S Núñez, LR Castro, K Riquelme, C Alarcón, C Oyarzún \& A Sepúlveda. 2007. Spawning, daily egg production and spawning stock biomass estimation for common sardine (Strangomera bentincki) and anchova (Engraulis ringens) off central southern Chile in 2002. Fisheries Research 86: 228-240.

Fischer W. 1958. Primeras fases del desarrollo del blanquillo (Prolatilus jugularis) Cuv. et Val. (Pisces). Revista de Biología Marina 8(1-3): 3-27.

Fischer W. 1959. Huevos, crías y prelarvas de la merluza (Merluccius gayi). Revista de Biología Marina 8: 224-249.

García-Godos I \& E Goya. 2006. Diet of the Peruvian diving petrel Pelecanoides garnotii at La Vieja island, Peru, 1997-2000: potential fishery interactions and conservation implications. Marine Ornithology 34: 33-41.

Gaughan DJ, WJ Fletcher \& KV White. 2001. Growth rate of larval Sardinops sagax from ecosystems with different levels of productivity. Marine Biology 139: 831-837.

González P \& C Oyarzún. 2003. Diet of the Chilean sandperch, Pinguipes chilensis (Perciformes, Pinguipedidae) in southern Chile. Journal of Applied Ichthyology 19: 371375.

Graham WM, JG Field \& DC Potts. 1992. Persistent 'upwelling shadows' and their influence on zooplankton distributions. Marine Biology 114: 561-570.

Henríquez LA, G Daneri, CA Muñoz, P Montero, R Veas \& AT Palma. 2007. Primary production and phytoplanktonic biomass in shallow marine environments of central Chile: effect of coastal geomorphology. Estuarine, Coastal and Shelf Science 73: 137-147.

Hernández EH \& LR Castro. 2000. Larval growth of the anchoveta Engraulis ringens during the winter spawning season off central Chile. Fishery Bulletin 98: 704-710.
Hernández-Miranda E, AT Palma \& FP Ojeda. 2003. Larval fish assemblages in nearshore coastal waters off central Chile: temporal patterns. Estuarine, Coastal and Shelf Science 53: 1075-1092.

Herrera G, E Tarifeño \& MC Orellana. 1987. Descripción de huevos y primeras fases larvales de la sardina común (Strangomera bentincki) y del machuelo (Ethmidium maculatum). Biología Pesquera 16: 107-113.

Herrera G, E Aguilera, G Castillo \& P Bernal. 1985. Growth of anchovy larvae Engraulis ringens in central Chile, determinated by daily increment count in otolith. Biología Pesquera 14: 11-15.

Jeffrey JA \& CT Taggart. 2000. Growth variation and water mass associations of larval silver hake (Merluccius bilinearis) on the Scotian shelf. Canadian Journal of Fisheries and Aquatic Science 57: 1728-1738.

Kokita T \& M Omori. 1998. Early life history traits of the gold-eye rockfish, Sebastes thompsoni, in relation to successful utilization of drifting seaweed. Marine Biology 132: 579-589.

Laidig TE, S Ralston \& JR Bence. 1991. Dynamics of growth in the early life history of shortbelly rockfish, Sebastes jordani. Fishery Bulletin 89: 611-621.

Laidig TE, KM Sakuma \& MM Nishimoto. 1996. Description of pelagic larval and juvenile stripetail rockfish, Sebastes saxicola (family Scorpaenidae) with an examination of larval growth. Fishery Bulletin 94: 289-299.

Landaeta MF \& LR Castro. 2006a. Variabilidad estacional en los patrones espaciales de las asociaciones ictioplanctónicas de la zona de fiordos de Chile austral. Ciencia y Tecnología del Mar 29(2): 107-127.

Landaeta MF \& LR Castro. 2006b. Spawning and larval survival of the Chilean hake Merluccius gayi under later summer conditions in the Gulf of Arauco, central Chile. Fisheries Research 77: 115-121.

Landaeta MF \& LR Castro. 2006c. Larval distribution and growth of the rockfish, Sebastes capensis (Sebastidae, Pisces), in the fjords of southern Chile. ICES Journal of Marine Science 63: 714-724.

Landaeta MF, R Veas, J Letelier \& LR Castro. 2008. Larval fish assemblages off central Chile upwelling ecosystem. Revista de Biología Marina y Oceanografía 43(3): 569-584.

Landaeta MF, GA Herrera, M Pedraza, CA Bustos \& LR Castro. 2006. Reproductive tactics and larval development of bigeye flounder, Hippoglossina macrops, off central Chile. Journal of Marine Biological Association of the United Kingdom 86: 1253-1264.

Lett C, P Penven, P Ayón \& P Fréon. 2007. Enrichment, concentration and retention processes in relation to anchovy (Engraulis ringens) eggs and larvae distributions in the northern Humboldt upwelling ecosystems. Journal of Marine Systems 64: 189-200.

Marín VH, LE Delgado \& R Escribano. 2003. Upwelling shadows in Mejillones Bay (northern Chilean coast): a remote sensing in situ analysis. Investigaciones Marinas 31(2): 47-55. 
Montero P, G Daneri, LA Cuevas, HE González, B Jacob, L Lizárraga \& E Menschel. 2007. Productivity cycles in the coastal upwelling area off Concepción: The importance of diatoms and bacterioplankton in the organic carbon flux. Progress in Oceanography 75: 518-530.

Neira FJ, AG Miskiewicz \& T Trnski. 1998. Larvae of temperate Australian fishes. Laboratory guide of larval fish identification, 474 pp. University of Western Australia Press, Nedlands.

Oyarzún C, C Fernández, M Landaeta \& N Cortés. 2001. Ontogenetic and temporal fluctuations in feeding habits of the Chilean croaker Cilus gilberti (Perciformes, Sciaenidae) in southern Chile. Cahiers de Biologie Marine 42: 295-302.

Palma AT, LA Henríquez \& FP Ojeda. 2009. Phytoplanktonic primary production modulated by coastal geomorphology in a highly dynamic environment of central Chile. Revista de Biología Marina y Oceanografía 44(2): 325-334

Palma AT, LM Pardo, R Veas, C Cartes, M Silva, K Manriquez, A Díaz, C Muñoz \& FP Ojeda. 2006. Coastal brachyuran decapods: settlement and recruitment under contrasting geometry conditions. Marine Ecology Progress Series 316: 139-153.

Parada CE, MA Sobarzo, D Figueroa \& L Castro. 2001. Circulación del Golfo de Arauco en un periodo transicional estacional: un nuevo enfoque. Investigaciones Marinas 29(1): 11-23.

Pedraza-Garcia M \& LA Cubillos. 2008. Population dynamics of two small pelagic fish in the central-south area off Chile: delayed density-dependence and biological interaction. Environmental Biology of Fishes 82: 111-122.

Pepin P \& TH Shears. 1997. Variability and capture efficiency of bongo and Tucker trawl samplers in the collection of ichthyoplankton and other macrozooplankton. Canadian Journal of Fisheries and Aquatic Science 54: 765-773.

Poulin E, AT Palma, G Leiva, D Narvaez, R Pacheco, SA Navarrete \& JC Castilla. 2002. Avoiding offshore transport of competent larvae during upwelling events: the case of the gastropod Concholepas concholepas in central Chile. Limnology and Oceanography 47(4): 1248-1255.

Sakuma KM \& TE Laidig. 1995. Description of larval and pelagic juvenile chilipepper, Sebastes goodie (family Scorpaenidae), with an examination of larval growth. Fishery Bulletin 93: 721-731.

Sepúlveda F, SL Marín \& J Carvajal. 2004. Metazoan parasites in wild fish and farmed salmon from aquaculture sites in southern Chile. Aquaculture 235: 89-100.

Smith PE \& SL Richardson. 1977. Standard techniques for pelagic fish eggs and larvae. FAO Fisheries Technical Paper 175: 1-107.
Sobarzo M, D Figueroa \& L Djurfeldt. 2001. Upwelling of subsurface water into the rim of the Biobío submarine canyon as a response to surface winds. Continental Shelf Research 21: 279-299.

Sobarzo M, RK Shearman \& S Letz. 2007. Near-inertial motions over the continental shelf off Concepción, central Chile. Progress in Oceanography 75: 348-362.

Soto KH, AW Trites \& M Arias-Schreiber. 2006. Changes in diet and maternal attendance of South American sea lions indicate changes in the marine environment and prey abundance. Marine Ecology Progress Series 312: 277-290.

Vargas CA, SE Araneda \& G Valenzuela. 2003. Influence of tidal phase and circulation on larval fish distribution in a partially mixed estuary, Corral Bay, Valdivia. Journal of the Marine Biological Association of the United Kingdom 83: 217-222.

Vargas M, S Cifuentes \& E Emparanza. 1999. Trophic spectrum of concurrent fish in the Playa Chipana reproduction area $\left(21^{\circ} 19^{\prime} \mathrm{S}-70^{\circ} 04^{\prime} \mathrm{W}\right)$, north of Chile. Revista de Biología Tropical 47: 597-600.

Vegas GE \& G Pequeño. 1993. Contribución al conocimiento biológico de Normanichthys crockeri Clark 1937 (Osteichthyes, Scorpaeniformes). Revista de Biología Marina 28: 1-36.

Vélez JA, W Watson, EM Sandknop, W Arntz \& M Wolff. 2003. Larval and osteological development of the mote sculpin (Normanichthys crockeri) (Pisces: Normanichthtydae) from the Independencia Bight, Pisco, Peru. Journal of Plankton Research 25(3): 279-290.

Vélez JA, W Watson, W Arntz, M Wolff \& SB SchnackSchiel. 2005. Larval fish assemblages in Independencia Bay, Pisco, Peru: temporal and spatial patterns. Marine Biology 147: 77-91.

Wing SR, LW Botsford, SV Ralston \& JL Largier. 1998. Meroplanktonic distribution and circulation in a coastal retention zone of the northern California upwelling system. Limnology and Oceanography 43(7): 1710-1721.

Yannicelli B, LR Castro, W Schneider \& M Sobarzo. 2006a. Crustacean larvae distribution in the coastal upwelling off central Chile. Marine Ecology Progress Series 319: 175189.

Yannicelli B, LR Castro, A Valle-Levinson, L Atkinson \& D Figueroa. 2006b. Vertical distribution of decapod larvae in the entrance of an equatorward facing bay of central Chile: implications for transport. Journal of Plankton Research 28(1): 19-37.

Zar JH. 1999. Biostatistical analysis, 663 pp. Prentice Hall, Englewood Cliffs.

Recibido el 15 de octubre de 2009 y aceptado el 16 de marzo de 2010 